\title{
Human papillomavinus 16 E6 oncoprotein binds to interferon regulatory factor-3 and inhibits its transcriptional activity
}

\author{
Lucienne V. Ronco, ${ }^{1}$ Alla Y. Karpova, ${ }^{1}$ Marc Vidal, ${ }^{2}$ and Peter M. Howley ${ }^{1,3}$ \\ ${ }^{1}$ Department of Pathology, Harvard M edical School, Boston, Massachusetts 02115 USA; ${ }^{2} \mathrm{H}$ arvard M edical School \\ and Massachusetts General Hospital Cancer Center, Charlestown, Massachusetts 02129 USA
}

\begin{abstract}
Interferon regulatory factor-3 (IRF-3) was found to specifically interact with HPV16 E6 in a yeest two-hybrid screen. IRF-3 is activated by the presence of doublestranded RNA or by virus infection to form a stable complex with other transcriptional regulators that bind to the regulatory elements of the IFN $\beta$ promoter. We show that IRF-3 is a potent transcriptional activator and demonstrate that HPV16 E6 can inhibit its transactivation function. The expression of HPV16 E6 in primary human keratinocytes inhibits the induction of IFN $\beta$ mRNA following Sendai virus infection. The binding of HPV16 E6 to IRF-3 does not result in its ubiquitination or degradation. We propose that the interaction of E6 with IRF-3 and the inhibition of IRF-3's transcriptional activity may provide the virus a means to circumvent the nomal antiviral response of an HPV16-infected cell.
\end{abstract}

[Key Words: IRF-3; HPV16; transcription; protein-protein interactions; oncoprotein]

Received N ovember 14, 1997; revised version accepted A pril 27, 1998.

The papill omavi ruses (PVs) display a specific tropism for squamous epithelial cells and produce benign cutaneous or squamous mucosal proliferative lesions. PVs often establish persistent or latent infections, and the virus productive life cycle is linked to the differentiation program of the infected squamous cell. Several of the PVs, including the human papillomaviruses (HPVs) that have been associated with cervical cancer, encode transforming genes whose functions create a cellular environment that all ows replication of the viral DNA. Relatively little is known, however, about other essential viral functions that are necessary to establish a state of persistent infection, to circumvent the cellular anti-viral mechanisms, or to evade the host immune response (Howley 1996).

A close association between cervical cancer and the HPVs has now been established (zur Hausen 1996). Over 70 different types of HPV have been identified and a subset of these has been found in $>90 \%$ of cervical cancers (Bosch et al. 1995). These high-risk HPV types include HPV16, HPV18, HPV31, and HPV33, and a number of additional related viruses. HPV16 DNA can be found in $>50 \%$ of cervical cancers. Functional studies of the early region of high-risk HPV virus genomes have demonstrated that two early viral genes, E6 and E7, are both necessary and sufficient for the efficient immortalization of primary human keratinocytes in vitro (HawleyNelson et al. 1988; Münger et al. 1989; Hudson et al.

${ }^{3}$ Corresponding author.

E-MAIL phowley@warren.med.harvard.edu: FAX (617) 432-2882.
1990). The major mechanism by which E6 and E7 contribute to immortalization is by targeting two distinct cellular tumor suppressor proteins for inactivation or degradation. E7 binds and inactivates the retinobl astoma tumor suppressor protein (pRB) and two closely related proteins, p107 and p130, leading to the activation of E2F responsive genes and the loss of $a G_{1}$ checkpoint (Jones and $M$ ünger 1996). E6 forms a ternary complex with p53 and the E6AP ubiquitin protein ligase resulting in the ubiquitination and degradation of p53 (Scheffner et al. 1990; Werness et al . 1990; Huibregtse et al. 1991, 1993a). Loss of p53 results in deregulated cellular growth and genomic instability, both of which are characteristics of immortalized cells (Hartwell 1992).

We have focused our studies on E6 because several lines of evidence suggest that the $E 6$ protein retains functions in addition to its ability to target the ubiquitination of p53. For instance, whereas p53 deficient mice display normal lens development, transgenic mice expressing HPV16 E6 in the lens are impaired in the normal pattern of differentiation, which include fiber cell denucleation and apoptotic-like DNA degradation (Pan and Griep 1994). In addition, E6 can increase cellular telomerase activity in the absence of p53 degradation (Klingel hutz et al. 1996). Furthermore, it is highly likely that E6 has functions in addition to those that are re vealed in transformation or differentiation assays. For instance, E6 can modulate the transcriptional activity of several cellular and viral promoters in both a p53 dependent and independent manner (Desaintes et al. 1992; 
Etscheid et al. 1994; Shirasawa et al. 1994; Shino et al. 1997). HPV16 E6 like BPV1 E6 can interact with the focal adhesion protein paxillin and, for BPV1 E6, this interaction has been shown to result in the disruption of the actin cytoskel eton (Tong and Howley 1997). Finally, E6 molecules have also been shown to interact with ERC 55, a putative calcium binding protein, although the physiologic consequence of this interaction is unclear (Chen et al. 1995).

Little is known about what regulates the PV life cycle or the antiviral response of squamous epithelial cells to a PV infection. An initial PV infection is associated with little or no inflammation, perhaps because of the lack of induction of cell death and release of viral antigen, or to viral interference with some specific aspect of the host immune response. There is little or no immune recognition of an early PV infection despite the ability of keratinocytes to serve as semiprofessional antigen presenting cells (Frazer 1996). DN A viruses have developed a variety of ways to overcome interferon (IFN) inhibitory effects and to evade host immunity (Vilcek and Sen 1996). To date however, the mechanisms by which the PVs may affect these pathways have not been el ucidated.

Type I IFN production is stimulated early in the course of a viral infection, and IFN production is an important determinant of the course of the subsequent disease (De Maeyer and De Maeyer-Guignard 1988; Muller et al. 1994). IFN s act directly on the virally infected cell by interfering with viral replication and by inhibiting celIular proliferation. To carry out these functions, IFN s impinge on many mechanisms ranging from inhibition of viral penetration and uncoating, to reduction of mRN A stability and protein production. Immunomodulatory activities of IFN s al so contribute to their antiviral roles. IFNs enhance the expression of cellular proteins such as MHC class I molecules that contribute to immune-mediated lysis of virus-infected cells (De M aeyer and De M aeyer-Guignard 1988). In addition, IFN production, stimulated by viral infection, is responsible for the activation and proliferation of natural killer cells, which act to lyse virus infected cells and to activate the immune system (Brutkiewiewicz and Welsh 1995).

To identify additional cellular targets of HPV 16 E6 involved in various aspects of the viral pathogenic mechanism, we carried out a yeast two-hybrid screen. Two independent human cDNAs were identified that interacted with HPV-16 E6. One of these clones was interferon regulatory factor-3 (IRF-3) (Au et al. 1995). A structurally rel ated group of transcription factors, the interferon $\alpha$-stimulated gene factor (ISGF) or IRF family, has been implicated in the mediation of cellular responses to IFN and to a variety of other cytokines (Vilcek and Sen 1996). IRF-3 was initially identified by its homology to other IRF family members. It was characterized as a transcriptional activator that could bind to the interferon-stimulated response el ement (ISRE). Its antiviral and interferon signaling activities were initially unclear because IRF-3 mRNA levels were not inducible by IFN or viral infection (Au et al. 1995). Recent studies, however, have shown that IRF-3 is part of a virus acti- vated transcription factor complex and that its transcriptional activity is increased in response to viral infection (Fujita et al. 1989; Schafer et al. 1998; Wathelet et al. 1998; Weaver et al. 1998).

IRF family members are believed to play a critical role in the regulated expression of the IFN $\alpha$ and $\beta$ genes. IRF-1 in particular can activate transcription from the ISRE, which is present in the promoters of genes activated by IFN and virus infection. In addition, some members of the IRF family are involved in a variety of cellular growth control mechanisms. To date, seven human members of this family have been characterized: IRF-1, IRF-2, IRF-3, IRF-4, IRF-7, IFN consensus sequence binding protein (ICSBP), and ISGF3 $\gamma$. IRF-1 has been characterized as a transcriptional activator and an antioncogene whose functional loss contributes to aberrant cellular growth (Fujita et al. 1989; Harada et al. 1990, 1993; Reis et al. 1992). The role of IRF-1 as a tumor suppressor is supported by the finding that IRF-1-deficient mouse embryonic fi broblasts readily undergo c-Haras-induced transformation (Tanaka et al. 1994). IRF-2 can repress IRF-1-stimulated transcription and exhibits oncogenic activity (Harada et al. 1990, 1993). Recently, IRF-2 was also characterized as a transcriptional activator that can activate transcription of the human histone $\mathrm{H} 4$ gene in a cell-cycle-dependent manner Naughan et al. 1995). IC SBP expression is restricted to the immune system and IC SBP can interact with both IRF-1 and IRF-2 at the ISRE to suppress IFN -inducible gene transcription (Driggers et al . 1992; N elson et al. 1993; Bovolenta et al. 1994). ISGF3 $\gamma$ (p48) is a positive regulator of IFN $\alpha$-stimulated transcription and forms the ISGF3 complex together with the Stat1 and Stat2 proteins. IRF-4 is a B cell-specific factor that associates with PU 1 and binds to the light-chain geneenhancer (Levy et al. 1988; Eisenbeis et al. 1995). It is essential for B and T cell function and homeostasis (M ittrucker et al. 1997). IRF-7 can repress transcriptional activation by IFN and IRF-1 (Zhang and Pagano 1997). Each member of this family can be stimulated to bind DN A and activate or repress gene transcription upon treatment of cells with cytokines, growth factors, double-stranded RNA, or viral infection.

We have found that the E6 protein encoded by HPV16 can bind to IRF-3. IRF-3 can stimulate transcription from a luciferase reporter construct containing tandem ISRE sites, and as a fusion protein with the Gal 4 DN A binding domain it can activate transcription from a chloramphenicol acetyltransferase (CAT) reporter plasmid containing five repeats of the Gal4 binding site. We show that HPV 16 E6 does not target IRF-3 for degradation. The interaction of HPV16 E6 with IRF-3 is specific and results in a marked reduction of the IRF-3 transactivation function in vivo. Finally, HPV16 E6 expression in primary keratinocytes significantly dampens the induction of IFN $\beta$ mRNA after viral infection. These results suggest a novel function for E6 that may be relevant to the life cycle of the PV. The interaction of HPV16 E6 with IRF-3 and the inhibition of its transactivation function could contribute to the ability of the virus to disrupt the cellular antiviral response. Furthermore, it is possible 
that the interaction of E6 with IRF-3 could be related to the oncogenic potential of the virus, affecting either the regulation of cellular proliferation or apoptosis, or through a perturbation of the ability of the immune system to recognize an HPV16-infected cell.

\section{Results}

Identification of HPV16 E6-interacting proteins

HPV16 E6 protein fused to the Gal4 DNA-binding domain (amino acids 1-147) was employed as the bait in a yeast two-hybrid screen to identify additional cellular proteins whose interactions may be important for E6 functions. A cDN A library from activated human $T$ cells was screened $\left(4 \times 10^{6}\right.$ transformants) for interaction with the Gal4-HPV16 E6 fusion protein. Fifty-six independent col onies were sel ected for el evated expression of the HIS3 reporter gene on 3-aminotriazole (3AT)-containing plates. The corresponding Gal4-activation domain CDNA encoding plasmids were isolated and retransformed into fresh yeast cells. The interaction of these retransformed clones with HPV 16 E6 was tested under a series of selection conditions. In addition to growth on 3AT (Fig. 1), transformants were al so tested for $\beta$-galactosi dase production and growth on uracil-deficient plates (data not shown). One of these cDN As, found six times in the screen, was identified as IRF-3 by sequence analysis.

\section{IRF-3 interacts selectively with HPV16 E6}

To further characterize the association of IRF-3 with HPV 16 E6 and to determine whether the ability to interact with IRF-3 was shared among the E6 proteins encoded by other HPV types, we examined the in vitro interaction of full-length IRF-3 synthesized in Escherichia coli as a GST fusion protein (GST-IRF-3) with E6 proteins from both high and low-risk HPV types. HPV18, HPV16, HPV11, and HPV6 E6 were transcribed and translated in wheat germ extract and tested for interaction with GST-IRF-3. GST-IRF-3 interacted strongly with HPV16 E6, binding up to $41 \%$ of the input HPV 16 E6 protein in a number of experiments. In these experiments, HPV6, HPV11, and HPV18 E6 proteins interacted

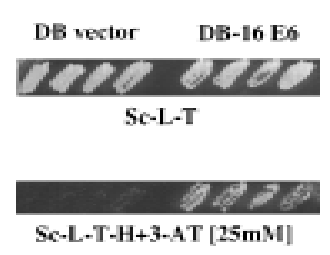

Figure 1. A yeast two-hybrid system was used to identify proteins that interact with HPV16 E6. The four patches of cells on the left of each plate contain empty Gal4 DB vector, pPC 97, and prey CDNA-AD vectors (AD-IRF-3). The four patches of cells on the right contain HPV16 E6-DB vector and AD-IRF-3. Patches of cells growing on plates selective for the presence of both plasmids (Sc-L-T-H) were replica plated onto plates lacking histidine and containing $25 \mathrm{~mm}$ 3AT (Sc-L-T-H +3AT). poorly with IRF-3, exhibiting only $1 \%-2 \%$ binding in vitro (Fig. 2A). The reciprocal experiment was conducted by use of GST-18 E6, GST-16 E6, and GST-11 E6 proteins and in vitro-translated IRF-3. Strong binding of IRF-3 with GST -16 E6 (53\% of input) and lesser binding with GST-18 E6 (5\% of input) was detected. No binding was seen between GST-11 E6 and IRF-3 (Fig. 2B). These results indicate that HPV16 E6 has the highest affinity for interaction with IRF-3. The ability of HPV16 E6 to bind IRF-3 cannot be dependent on the cellular factor E6AP because E6AP is not present in wheat germ extract (Huibregtse et al. 1991). Furthermore, in the presence of HPV16 E6, IRF-3 was not brought into a complex with E6AP (data not shown). Finally, HPV16 E6 does not target IRF-3 for ubiquitin-mediated degradation in vitro (data not shown).

To demonstrate an in vivo interaction of HPV16 E6 and human IRF-3, COS cells were transfected with plasmids expressing each protein individually or together. Figure $2 \mathrm{C}$ shows a coimmunoprecipitation of the AU 1tagged HPV16 E6 (Sherman and Schlegel 1996) and IRF-3 with the IRF-3-specific monoclonal antibody SL-12. SL12 was raised against human IRF-3 and has been used previously to immunopreci pi tate endogenous IRF-3 from human cells (Wathelet et al. 1998). SL-12 does not recognize monkey IRF-3 and does not detect IRF-3 in COS cells by Western analysis or by immunoprecipitation (data not shown). In the experiment depicted in Figure 2C, AU 1-tagged HPV16 E6 was detected by Western analysis with the AU 1 monoclonal antibody. Attempts to coimmunoprecipitate IRF-3 with the AU-1 antibody recognizing the tagged HPV16 E6 were not successful.

Because the members of the IRF transcription factor family share substantial sequence homology, we next examined whether HPV16 E6 could bind to other members of the IRF/ISGF family of proteins (Fig. 2D). IRF-1, IRF-2, ISGF3 $\gamma$, and ICSBP were tested for interaction with GST-16 E6 in vitro. HPV16 E6 exhibited weaker interaction with in vitro-translated IRF-1 (binding 7.6\% of input IRF-1) compared with IRF-3, and did not strongly interact with any other family members (Fig. 2D). GST -16 E6 bound 3\%, $1.5 \%$, and $2.5 \%$ of the input IRF-2, ICSBP, and ISGF3y proteins, respectively. These results suggest that HPV16 E6 specifically interacted with only a subset of the members of the IRF family in vitro, and that the strongest interaction was with IRF-3.

\section{Identification of the E6-binding region within IRF-3}

To map the domain of IRF-3 involved in binding to HPV16 E6, a series of carboxy-terminal del etion mutants of IRF-3 fused to GST were synthesized. Equal amounts of the GST fusion proteins $(\sim 0.15 \mu \mathrm{g})$ were assayed for their abilities to bind HPV16 E6 by mixing the GST fusion proteins, immobilized on glutathione-Sepharose, with ${ }^{35} \mathrm{~S}$-label ed, in vitro-translated HPV 16 E6. Figure 3B shows schematics of the IRF-3 proteins that were tested for interaction with HPV16 E6. Full-length IRF-3 was found to bind $42 \%$ of the HPV16 E6 present in the reaction mixture (Fig. 3A, lane 1). The two IRF-3 proteins 
A

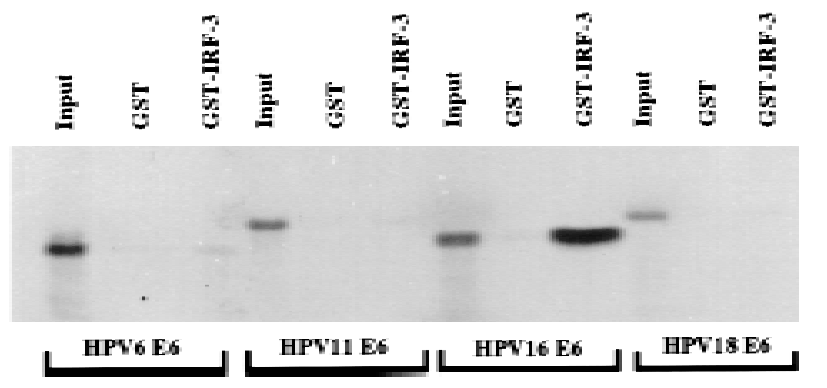

B

Figure 2. Analysis of the interactions between HPV E6 proteins and interferon regulatory factors (A) The indicated HPV E6 proteins were in vitro-translated in the presence of $\left[{ }^{35}\right.$ S]cysteine and methionine and mixed with GST-IRF-3 immobilized on glutathione-Sepharose. The complexes were washed to removed noninteracting proteins and resolved by PAGE. Input corresponds to $10 \%$ of protein used in the binding experiments. (B) IRF-3 was synthesized in rabbit reticulocyte lysate in the presence of ${ }^{35}$ S]cysteine and methionine and mixed with indicated GST al one or GST-E6 immobilized on glutathione-Sepharose. Complexes were washed and resolved by PAGE. Input corresponds to $50 \%$ of the protein used in the binding reactions. (C) COS-7 cells were el ectroporated with indicated constructs and after $36 \mathrm{hr}$, lysates were immunoprecipitated with control C, AU 1, or IRF-3 (SL-12) monoclonal antibodies. HPV16 E6 and the light chain are indicated by arrows. (D) Indicated IRF proteins were synthesized in rabbit reticulocyte lysate in the presence of ${ }^{35}$ S]cysteine and methionine and mixed with either GST or GST-E6 immobilized on glutationeSepharose. Complexes were washed and resolved by PAGE. Input corresponds to $50 \%$ of protein.
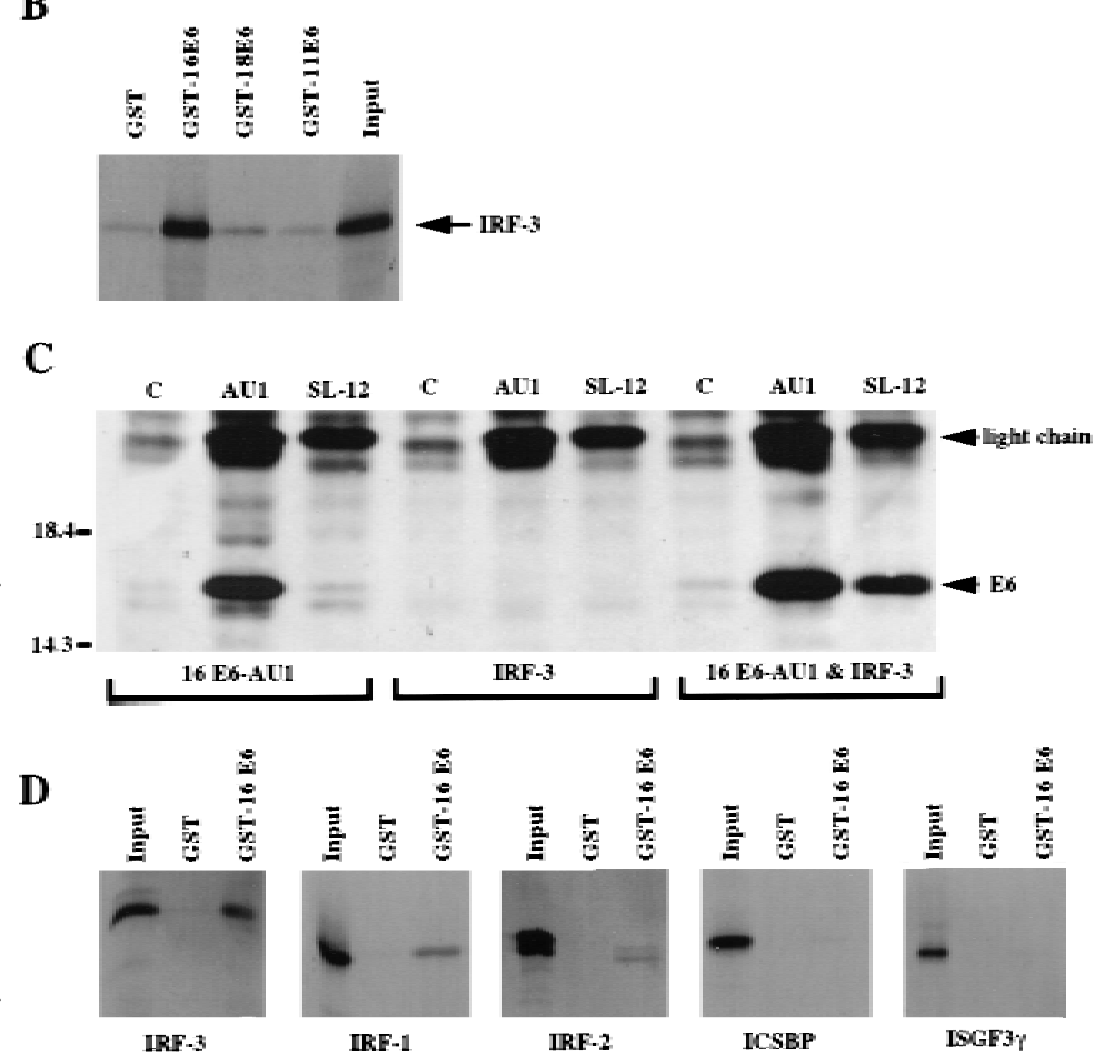

truncated at amino acids 244 and 149 bound $62 \%$ and $55 \%$ of the input E6, respectively (Fig. 3A, lanes 2 and 3). The amino-terminal portion of IRF-3 comprising amino acids 2-109 bound only $1 \%$ of the input E6 (Fig. 3A, lane 4). On close analysis, the portion of IRF-3 located between amino acids 109 and 149 was found to contain a stretch of amino acids (ELLG) that are present in the E6 binding domain of E6AP (Huibregtse et al. 1993b). This ELLG sequence has also been implicated as an E6 interaction domain by screening of a two-hybrid peptide library in which peptide sequences containing ELLG, or variants of it such as EFLG, ELVG, or DILG, were found to interact with HPV16 E6 (Elston et al. 1998).

HPV16 E6 expression does not promote the degradation of IRF-3 in human keratinocytes

To determine whether interaction of IRF-3 with E6 resulted in its ubiquitination and degradation, primary neonatal human foreskin keratinocytes (HFKs) were isolated and infected with a recombinant retrovirus carrying individual HPV16 genes (Hal bert et al. 1991). Western analyses to determine HPV16 E7, p53 and IRF-3 protein levels were conducted on lysates from HFKs infected with viruses expressing vector al one, HPV16 E6, E7, or E6 and E7. E7 expression was demonstrated in these cells by Western analysis (data not shown). Functional E6 production was determined by analysis of $\mathrm{p} 53$ protein levels. As expected, E6 expression led to a marked reduction in p53 protein levels (Fig. 4A); however, E6 did not affect the steady-state levels of IRF-3 (Fig. 4B). In addition, in vitro ubiquitination and degradation experiments were carried out and HPV16 E6 did not promote the ubiquitination or degradation of IRF-3 under conditions that led to the proteolysis of p53 (data not shown). Half-life determinations for p53 and IRF-3 were also conducted in HFK cells expressing the HPV viral oncoproteins. E6 expression resulted in a shortened 

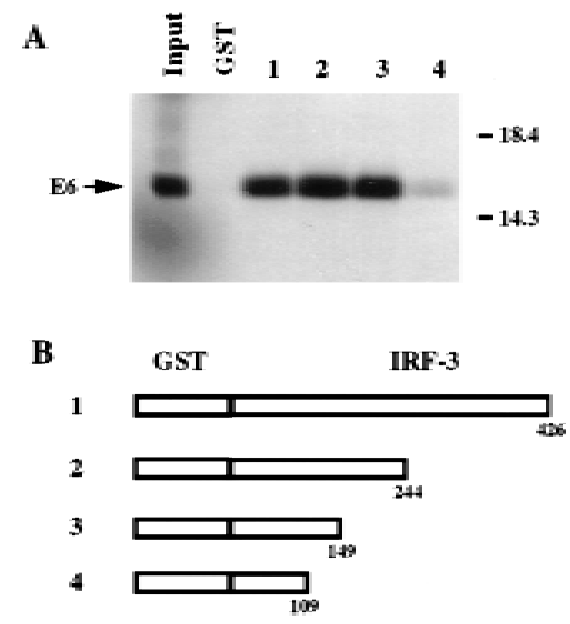

Figure 3. Mapping of the IRF-3 region that directs E6 binding. (A) Binding of HPV16 E6 to GST-IRF-3 proteins 1-5. HPV16 E6 was in vitro-translated in wheat germ extract in the presence of $\left[{ }^{35}\right.$ S]cysteine and methionine and mixed with the indicated GST-IRF-3 proteins as described previously. Input represents $50 \%$ of the E6 protein used in each assay. (B) Schematic representation of the GST-fused carboxy-terminal deletions and sitespecific mutation containing indicated portions of IRF-3. (Open boxes) IRF-3 coding sequences.

half-life for p53 in agreement with previous reports, but had no effect on the half-life of IRF-3. The IRF-3 protein in HFK was long-lived with a half-life of $>3 \mathrm{hr}$ (data not shown).

\section{IRF-3 is a potent transcriptional activator}

The initial published characterization of IRF-3 concluded that the protein did not contain a transcriptional activation domain (Au et al . 1995). In those experiments, the IRF-3 CDNA was fused in-frame to the DNA-binding domain of Gal4. Using a CAT reporter containing five Gal 4 binding sites upstream of a minimal thymidine kinase promoter to assay Gal4-IRF-3 transactivation function, Au et al. (1995) found Gal4-IRF-3 to be devoid of intrinsic transactivational activity in the murine fibroblast cell line L929. We also constructed an IRF-3 Gal4 DNA-binding domain fusion protein and assayed it for transcriptional activation capacity. In contrast to the previously published results, our experiments showed Gal4-IRF-3 to be a potent transcriptional activator in each of several different cell types tested, including C33A and U2OS cell lines.

Increasing concentrations of a Gal4-IRF-3 expressing plasmid were cotransfected into L929 cells with either a CAT reporter containing five Gal4 binding sites (5Gal4TKCAT) upstream of the thymidine kinase promoter, or a luciferase reporter containing five $\mathrm{Gal} 4$ binding sites upstream of a TATA box. Figure 5A shows representative luciferase assays comparing the transcriptional activity of Gal4-IRF-3 to that of Gal4-IRF-1 and Gal4-Stat 2. These results indicate that Gal4-IRF-3 is a 10- to 100fold more potent transcriptional activator than Gal4-
IRF-1 and possesses similar transcriptional activity as Gal4-Stat-2. Similar results were observed by use of a 5Gal4-CAT reporter.

\section{HPV16 E6 inhibits IRF-3 transactivation}

Several studies have suggested that HPV16 E6 may be able to modulate transcription of certain cellular genes (Dey et al. 1997; Kinoshita et al. 1997; Shino et al. 1997). To examine what effect HPV16 E6 might have on IRF-3 function in vivo, we ascertained whether HPV16 E6 could influence IRF-3 transactivation. In this assay, HPV 16 E6 and Gal4-IRF-3 were cotransfected into L929 cells with a Gal4-CAT reporter and a $\beta$-galactosidase indicator plasmid. Transfection of increasing concentrations of plasmid DNA expressing HPV16 E6 (p1436) (Münger et al. 1989) resulted in a dose-dependent inhibition of IRF-3 transactivation (Fig. 5B). Similar results were observed by use of a Gal4-luciferase reporter and in the cervical carcimona cell line C 33A (data not shown). A reduction of $>85 \%$ in the levels of IRF-3 transactivation was observed at the highest concentration of HPV16 E6 plasmid. In contrast, transfection with HPV6 E6 at similar plasmid concentrations did not impair IRF-3 transactivation (Fig. 5C). Because of the lack of sensitive antibodies to the E6 proteins, we were unable to measure and compare the HPV 16 and HPV6 E6 protein levels in these experiments. However, we have confirmed expression from both constructs by $\mathrm{N}$ orthern anal ysis (data not shown) and both constructs have been demonstrated to have activity in human mammary epithelial cell immortalization assays suggesting that both constructs encode a functional E6 protein (Band et al. 1993). The results presented here are consistent with our in vitro binding results that showed binding of HPV16 E6 but not of HPV6 E6 to IRF-3. Because a low level of HPV16 E6 binding to IRF-1 was observed in the GST binding stud-

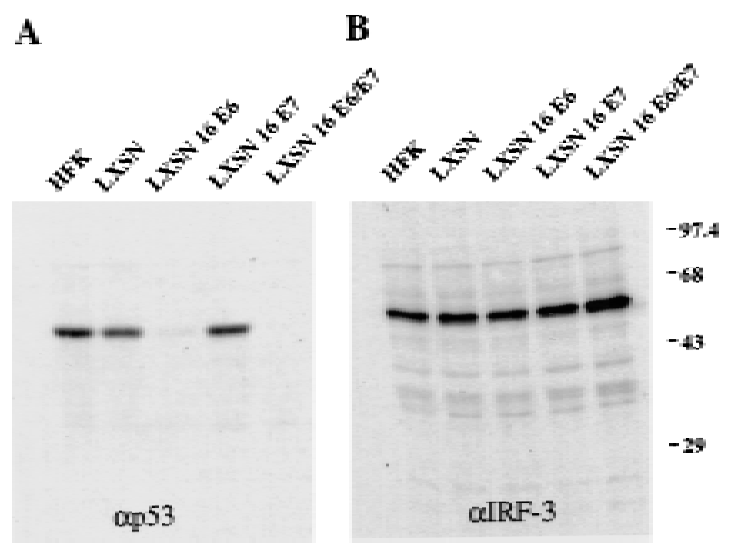

Figure 4. HPV16 E6 expression does not promote IRF-3 degradation in vivo. Immunoblot analysis of $100 \mu \mathrm{g}$ of total protein Iysates from HFK cells expressing HPV ORFs as indicated. (A) Western blot probed with p53-specific antibody, Ab6 (Calbiochem). (B) Western blot probed with IRF-3-specific monoclonal antibody, SL-12. High range molecular weight protein standards are indicated (GIBCO-BRL). 
Figure 5. Stimulation of 5Gal4-TK-luciferase expression by Gal4-IRF-3, Gal4-IRF-1, and Gal4-Stat-2 and dose-dependent inhibition of IRF-3 transactivation by HPV16 E6. (A) L929 cells were cotransfected with $2 \mu \mathrm{g}$ of the 5Gal4-TK-luciferase reporter construct and increasing amounts of Gal4-IRF-3 (ם),

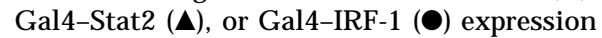
plasmids. (B) L929 cells were cotransfected with $1 \mu \mathrm{g}$ of SV40- $\beta$-gal, $2 \mu \mathrm{g}$ of the $5 \mathrm{Gal} 4-$ E1bTATA-CAT reporter (pG4BCAT) and 0.1 $\mu \mathrm{g}$ of Gal4-IRF-3 expression construct and increasing amounts of the HPV16 E6 expression plasmid p1436. (C) L929 cells were cotransfected with $1 \mu \mathrm{g}$ of SV $40-\beta$-gal, $2 \mu \mathrm{g}$ of the 5Gal 4-TKCAT reporter, $0.1 \mu \mathrm{g}$ of Gal4-IRF-3 expression construct and increasing amounts of p1436. (D) L929 cells were cotransfected with $1 \mu \mathrm{g}$ of SV40- $\beta$-gal , $2 \mu \mathrm{g}$ of the $5 \mathrm{Gal} 4-\mathrm{TK}$-luciferase reporter, $1 \mu \mathrm{g}$ of a Gal4-IRF-1 expression construct and increasing amounts of the HPV6 E6 expression plasmid p1478. (E) L929 cells were cotransfected with $1 \mu \mathrm{g}$ of SV40- $\beta$-gal, $2 \mu \mathrm{g}$ of the 5Gal4-TKCAT reporter, $0.1 \mu \mathrm{g}$ of Gal $4-S t a t 2$ expression construct and increasing amounts of p1436. (F) C33A cells were cotransfected with $0.5 \mu \mathrm{g}$ of SV $40-\beta$-gal, $0.25 \mu \mathrm{g}$ of the ISG 15-ISRE luciferase reporter, $0.5 \mu \mathrm{g}$ of pCDN A 3-IRF-3 and increasing amounts of p1436. The levels indicated were derived from duplicate samples within each experiment and are means from at least three independent experiments. CAT and luciferase activities were normalized to $\beta$-gal actosidase expression levels. Error bars, standard error.

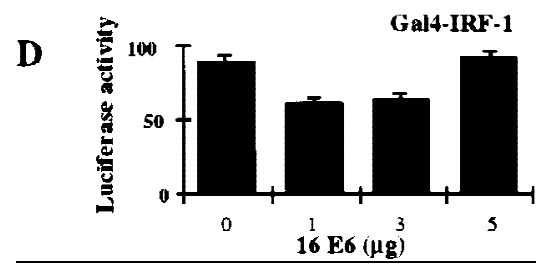

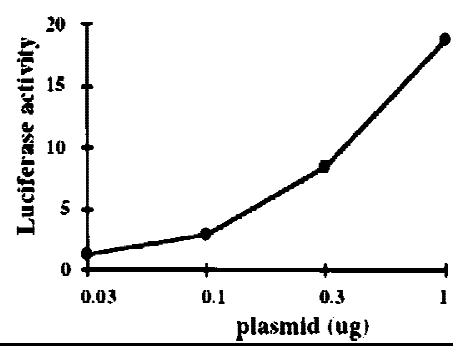

B
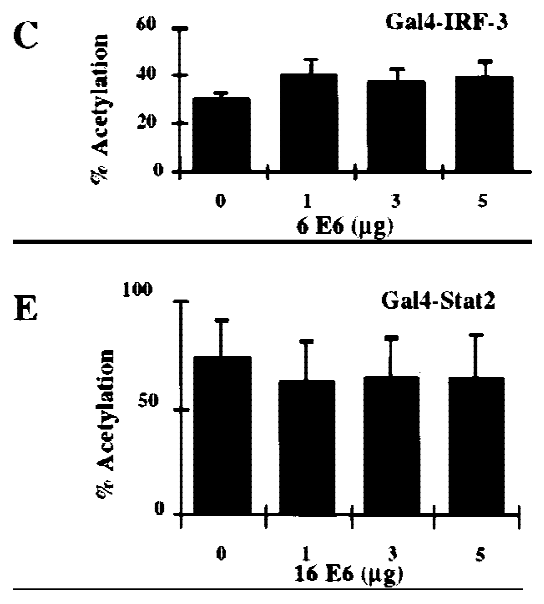

$\mathbf{F}$

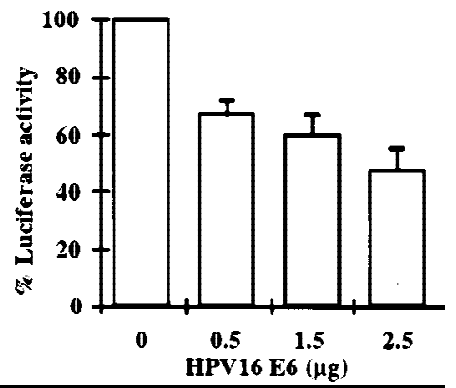

ies (Fig 2C), we next determined what effect HPV16 E6 expression had on IRF-1 transactivation in vivo. Because Gal4-IRF-1 is a relatively weak transactivator, the more sensitive luciferase reporter system was used. Cotransfection of HPV16 E6 with Gal4-IRF-1 had no effect on IRF-1 transactivation (Fig. 5D). To further determine whether HPV16 E6 inhibition of IRF-3 transactivation was specific, experiments were conducted with Gal 4-Stat2. HPV16 E6 had no effect on Stat-2 transactivation (Fig. 5E). T aken together, these results suggest that the ability to impair IRF-3 transactivation was specific for a high risk form of E6, and that HPV16 E6 does not have a general inhibitory effect on transactivation. Furthermore, the relatively weak interaction of HPV16 E6 with IRF-1 observed in vitro does not appear to be physiologically significant because HPV16 E6 had no effect on IRF-1 dependent transactivation in vivo.

We have demonstrated that HPV16 E6 can inhibit IRF-3 transactivation when IRF-3 binds DNA via the Gal4 DNA-binding domain. Next, we determined whether HPV16 E6 affected the transactivati on capacity of IRF-3 acting on the ISRE. It was demonstrated previously that cotransfection of IRF-3 (not as a Gal 4 fusion) with the ISG 15 promoter inserted upstream of the CAT reporter gene resulted in a dose-dependent increase in CAT activity (Au et al. 1995). Therefore, we examined the activity of IRF-3 at a promoter containing three copies of the ISG 15 ISRE. The HPV negative human cervical carcinoma cell line C33A was used for these experiments to demonstrate that this activity of HPV16 E6 is conserved in a human epithelial cell line. Because the p53 gene is mutated in C33A cells (Scheffner et al. 1991), these experiments also allowed us to determine the effect of HPV16 E6 on IRF-3 transactivation in the absence of wild-type p53. As seen with the Gal4-IRF-3 experiments, increasing concentrations of the HPV16 E6 plasmid resulted in a dose-dependent inhibition of IRF-3 transactivation at the ISRE (Fig. 5F). In these experiments, we consistently observed $40 \%-70 \%$ inhibition of IRF-3 transactivation at the highest transfected concentration of the HPV16 E6 expression plasmid. Comparable results were found in L929 and U2OS cells (data not shown). 


\section{E6 inhibits the viral induction of IFN $\beta$ mRNA}

Wathelet et al. (1998) have demonstrated that viral infection leads to the phosphorylation and nuclear translocation of IRF-3 and its incorporation into a complex designated the virus-activated factor (VAF). Once activated, VAF binds to the ISRE-like elements in virus-inducible promoters and promotes transcription (Fujita et al. 1989; Schafer et al. 1998; Wathelet et al. 1998; Weaver et al. 1998). IFN $\beta$ then activates a complex antiviral celIular response. Therefore, we asked whether HPV16 E6 had an effect on the induction of IFN $\beta$ by virus infection. Primary human keratinocytes stably expressing HPV16 E6, HPV6 E6, or HPV16 E7 were infected with Sendai virus and the induction of IFN $\beta$ mRNA was determined by $\mathrm{N}$ orthern analysis (Fig. 6A). The expression of HPV16 E6 resulted in a $44 \%$ inhibition of IFN $\beta$ mRN A production. Expression of HPV6 E6 or HPV16 E7 had no effect on the induction of IFN $\beta$ mRNA. IRF-3 has been found to be directly activated by viral infection resulting in the production of IFN $\beta$. Type I IFN treatment of cells induces the production of a variety of IFN -inducible transcripts. The $2^{\prime}-5^{\prime}(A)$ synthetase family of enzymes activates a latent ribonuclease that can cleave singlestranded RNAs (Vilcek and Sen 1996). To determine whether HPV16 E6 could affect the induction of the $2^{\prime}-5^{\prime}(A)$ synthetase, the N orthern bl ot was stripped and
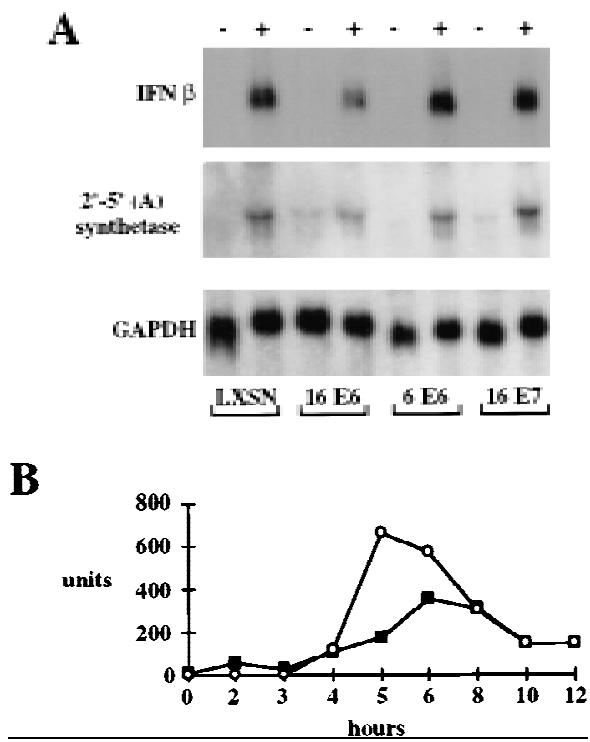

Figure 6. HPV16 E6 impairs virus induction of IFN $\beta$. (A) A $\mathrm{N}$ orthern blot, containing $7.5 \mu \mathrm{g}$ of total cell RN A isolated from the indicated cell lines $5 \mathrm{hr}$ after Sendai virus infection, was hybridized with an IFN $\beta$-specific probe (top), with a $2^{\prime}-5^{\prime}$ (A) specific probe (middle), or with a GAPDH probe (bottom). After hybridization and washing, filters were exposed to X-ray film for 18,24 , and $26 \mathrm{hr}$, respectively. (B) N orthern blots, containing $7.5 \mu \mathrm{g}$ of total cellular RNA isolated at indicated times after virus infection from HPV16 E6 (ם)- and HPV6 E6 (O)-expressing HKFs, were hybridized with an IFN $\beta$-specific probe or with $a$ GAPDH probe. Specific signals were quantitated by PhosphorImager analysis and the IFN $\beta$ levels were normalized to GAPDH levels at each time point. probed with the $2^{\prime}-5^{\prime}$ (A) synthetase CDN A. In the presence of HPV16 E6, the $2^{\prime}-5^{\prime}$ (A) synthetase mRNA was induced to $32 \%$ of the level found in cells expressing vector al one ( $L X S N)$. The induction of $2^{\prime}-5^{\prime}(A)$ synthase mRNA by viral infection is indirect (Wathelet et al. 1992) and our results suggest that the inhibitory effect of HPV16 E6 on IFN $\beta$ production is physiologically significant in that it can impair the induction of secondary antiviral transcripts.

To determine whether HPV16 E6 had an effect on the kinetics of IFN $\beta$ induction as well as the level of expression, we examined IFN $\beta$ expression in HFKs expressing HPV16 E6 or HPV6 E6 that had been infected with Sendai virus. Total cellular RNA was isolated at the indicted times and $N$ orthern blots were probed for IFN $\beta$ and GAPDH mRN As (Fig. 6B). The levels of IFN $\beta$ indicated were normalized by the amount of GAPDH present at each time. Although HPV16 E6 did not have a significant effect on the timing of IFN $\beta$ mRN $A$ induction, the extent of induction was impaired by $73 \%$ and $38 \%$ at 5 and $6 \mathrm{hr}$ after Sendai virus infection.

HPV16 E6 expression does not affect the stability of IRF-3 in human keratinocytes after Sendai virus infection

To determine whether the decrease in IRF-3 activity following Sendai virus infection resulted from the HPV16 E6 mediated degradation of IRF-3 protein, we examined the IRF-3 level s in HFK retrovirus vector control (LXSN) or HPV16 E6 expressing cells. Whole cell extracts harvested $0,3,4,5$, and $6 \mathrm{hr}$ after Sendai virus infection were analyzed by Western blot with the SL-12 antibody to detect IRF-3 levels. Interestingly, in the parental HFKs as well as the LXSN control HKFs, IRF-3 protein levels dropped dramatical ly $5 \mathrm{hr}$ after viral infection (Fig. 7A,B). Only a small amount of slower migrating IRF-3 protein could be detected at 5 and $6 \mathrm{hr}$ after infection. IRF-3 is phosphorylated as a consequence of viral infection. It is possible that the slower migrating forms of IRF-3 apparent at 5 and $6 \mathrm{hr}$ corresponded to phosphorylated IRF-3 (Fujita et al. 1989; Wathel et et al. 1998; Weaver et al. 1998). The level s of IRF-3 in HPV16 E6 expressing HFKs were similar to the levels in the LXSN control HFKs at each of the time points (Fig. 7A). To determine whether IRF-3 protein loss resulted from proteosome mediated degradation, parental HFK were treated with the proteosome inhibitor MG132 immediately prior to viral infection (Rock et al. 1994). M G132 stabilized IRF-3 after viral infection, indicating that the degradation of IRF-3 was proteosome mediated. Further experiments will be needed to address whether IRF-3 degradation involves ubiquitination.

\section{Discussion}

In this study we have found that HPV16 E6 can interact with IRF-3 and inhi bit its ability to transactivate. HPV16 E6 is required for the efficient immortal ization of human keratinocytes and has been implicated in the initial steps 


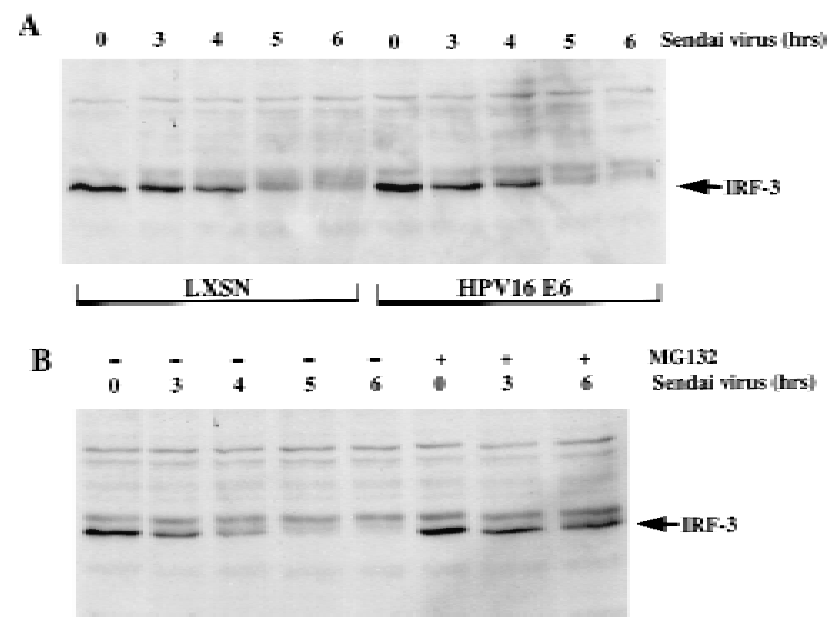

Figure 7. HPV16 E6 expression does not affect the stability of IRF-3 in human keratinocytes after Sendai virus infection. Immunoblot analyses of $100 \mu \mathrm{g}$ of total protein lysates from HFK cells. (A) Western bl ot of HFKs expressing vector al one (LXSN) or HPV16 E6 as indicated probed with SL-12. (B) Western bl ot of the parental HFKs probed with SL-12. Cells were treated with MG132 $(40 \mu \mathrm{m})$ immediately prior to virus infection. Total cell Iysates were harvested at the times indicated after Sendai virus infection.

of cellular transformation. IRF-3 was originally identified by its amino acid sequence homology to a family of structurally related transcription factors. The results presented here indicate that IRF-3 is a potent transcriptional activator and that the interaction of HPV16 E6 with IRF-3 inhibits this function in vivo. IRF-3 can activate transcription by binding to ISRE and ISRE-like elements in regulatory regions of genes activated by viral infection. IRF-3 has been shown recently to be an essential component of the VAF complex that transactivates the IFN $\beta$ promoter after viral infection (Fujita et al . 1989; Schafer et al. 1998; Wathelet et al. 1998; Weaver et al. 1998). We demonstrate here that E6 inhibition of IRF-3 transcriptional activity impairs the induction of IFN $\beta$ in response to viral infection. This represents the first description of a biochemical mechanism by which HPV modulates the antiviral activities of infected cells.

HPV16 E6 inhibited the transactivation of Gal4-IRF-3 by $85 \%$ at the highest E6 plasmid concentrations. The inhibitory effect of HPV16 E6 on intact IRF-3 transcriptional activity at the ISRE was more modest, $50 \%$. Similar levels of inhibition by HPV16 E6 were seen on the cellular promoter for IFN $\beta$ where HPV16 E6 reduced the response to virus infection by $38 \%$ to $73 \%$ depending on the experiment and time after Sendai virus infection. Multiple signal transduction pathways lead to activation of transcription factors including NFKB, ATF-2, and cJun, which converge to affect the expression of the IFN $\beta$ gene (Thanos and Maniatis 1995; Kim and Maniatis 1997). In addition, after viral infection, IRF-3 becomes part of a large complex that includes IRF-7, p300, and pCBP. The partial inhibitory effect of HPV16 E6 on the IFN $\beta$ promoter may be caused by the complex regulatory pathways that control expression from the IFN $\beta$ promoter. As demonstrated by the impaired induction of $2^{\prime}-5^{\prime}$ (A) synthetase, the inhibitory effect of HPV16 E6 on IRF-3 is sufficient to affect genes regulated by IFN $\beta$, thereby modulating the cellular physiologic response to viral infection.

It has been shown previously that HPV16 E6 can inhibit the transactivation function of p53 (Mietz et al. 1992). That inhibition is presumably the result of the interaction of E6 with the E6AP ubiquitin protein ligase and the formation of a ternary complex with p53, which results in the ubiquitination and degradation of p53. However, the effect of E6 on IRF-3 does not involve its proteolysis. The IRF-3 half-life and steady-state protein levels were unaffected by the expression of HPV16 E6. We have mapped the region of IRF-3 that is involved in HPV16 E6 binding. This region contains a motif similar to the one found within the E6 binding domain of E6AP (Huibregtse et al. 1993; Elston et al. 1998). This suggests that E6 may bind directly to IRF-3, and furthermore suggests that E6AP is not required for the interaction. In support of this, we have found that IRF-3 is not part of a complex with E6AP in the presence or absence of E6 (data not shown). We found that IRF-3 is degraded 5-6 hr after viral infection and that HPV16 E6 expression does not affect this degradation. We have begun to address the mechanism of IRF-3 loss after viral infection. The stabilization of IRF-3 by the proteosome inhibitor MG132 suggests that IRF-3 is targeted for degradation in a proteosome-dependent manner. Interestingly, the timing of the attenuation of IFN $\beta$ mRNA production in response to virus infection in HFK mirrors the timing of the degradation of IRF-3 (Figs. 6B and 7A,B). These results suggest that the regulated degradation of IRF-3 may be responsible for shutting off the IFN $\beta$ response.

The list of transcription factors that can act as bifunctional regulators of transcription, by activating gene expression from some promoters while repressing others, is quite large. HPV E6 proteins have transcriptional-modulatory activities, some of which are p53 dependent and some are p53 independent (Lamberti et al. 1990; Sedman et al. 1991; Mietz et al. 1992). HPV16 E6 can increase cellular fibronectin gene expression (Shino et al. 1997). HPV16 E6 can also transactivate the prothymosin $\alpha, \mathrm{C}-$ myc, and TGF- $\beta 1$ promoters (Dey et al. 1997; Kinoshita et al. 1997). Furthermore, both high-risk and low-risk HPV E6 proteins can transactivate the adenovirus E2 promoter as well as a number of viral TATA-containing promoters in NIH-3T 3 cells (Crook et al. 1991; Sedman et al. 1991; Desaintes et al. 1992). In contrast, H PV16 E6 can inhibit the activity of two viral promoters, the Molony murine leukemia virus LTR and the cytomegalovirus immediate early promoter (Etscheid et al. 1994). HPV16 E6 has been shown to localize to the nucleus as well as the cytoplasm, consistent with the studies implicating it with functions affecting transcription of specific genes (Androphy et al. 1987; Lechner et al. 1992). In this paper we demonstrate that HPV 16 E6 interacts very strongly with IRF-3 in vitro whereas HPV 18 E6 interacts only modestly with IRF-3. Similarly, in vitro-translated 
HPV18 E6 interacts less well with E6AP, however, HPV18 E6 does function in vivo to degrade p53. Experiments are ongoing to address whether HPV18 E6 can bind to IRF-3 in vivo and modulate its transcriptional activity.

IRF family members have been shown to be modulators of the cell cycle and of apoptosis, and may have functional similarities to p53. That IRF-1 can function as a tumor suppressor has been most cl early demonstrated in experiments that showed that embryonic fibroblasts from IRF-1 null mice could undergo transformation by the expression of c-Ha-ras alone (Tanaka et al. 1994). In addition, IRF-1 and p53 appear to cooperate in response to DNA damage and in the transcriptional activation of p21 (T anaka et al. 1996). Both IRF-1 and p53 are essential for DNA damage-induced apoptosis in $\mathrm{T}$ lymphocytes and in embryonic fibroblasts (Lowe et al. 1993; T anaka et al. 1994, 1996; T amura et al. 1995). Through these studies, the regulators of the IFN pathway have been linked to cellular transformation and apoptosis. HPV16 E6 can functionally impair p53, and from the experiments presented here, E6 can interfere with the function of an IRF family member. It is tempting to speculate that in addition to diminishing the cellular response to viral infection, the ability of E6 to interfere with keratinocyte differentiation and its potential to avert an apoptotic signal in a p53 independent manner may reside in part in its ability to interact with and modulate the activity of IRF-3.

\section{Materials and methods}

\section{Plasmids}

The Gal4 DNA-binding domain in pSG424 (Sadowski and Ptashne 1989) was fused to full-length IRF-3 residues 2-427. The Gal4-Stat2 plasmid contained residues 670-851 (Bhattacharya et al. 1996). The Gal4-IRF-1 plasmid contained the full-length IRF-1 residues 1-325, IFN $\beta$, and $2^{\prime}-5^{\prime}$ (A) synthetase CDNA containing plasmids were provided by $M$ arc Wathelet (Wathelet et al. 1992). The $\beta$-actin HPV16 E6 (p1436) and $\beta$ actin HPV6 E6 (p1478) plasmids were constructed by Karl Munger (Munger et al. 1989). GST-IRF-3 was constructed by cloning an EcoRI-Notl fragment from the yeast prey vector, pPC 86 into pG ex4T-1. Truncated forms of GST-IRF-3 were constructed by PCR cloning an EcoRI-Xhol fragment containing the indicated amino acids into pGex4T-1. Gal4-IRF-3 was constructed by cloning an Ecol-N otl fragment from the GST-IRF-3 construct into pSG424. The IRF-3 expression plasmid was cloned into pCDNA3 (Invitrogen) by PCR of the first 139 amino acids of IRF-3 containing an EcoRI-Xmnl fragment and ligation to the remaining portion of IRF-3 (Xmnl-Notl) derived from the yeast prey vector-IRF-3 plasmid. Plasmids used for in vitro translation of other IRF family members, IRF-1, IRF-2, ICSBP, and ISGF3 were kindly provided by Dr. K. Ozato (Bovolenta et al. 1994). Plasmids for in vitro translation of E6 proteins and GST-E6 plasmids have been desccribed previously (Werness et al. 1990; Huibregtse et al. 1993). The ISG 15-ISRE luciferase reporter was constructed by insertion of a HindlII-Sacl fragment containing three copies of the ISG 15 ISRE upstream of the Elb TATA box into the G5luciferase (G5luc) reporter plasmid (Deng and Karin 1993). All constructs generated by PCR were confirmed by DNA sequencing. Plasmids used for transfections were purified by $\mathrm{CsCl}$ gradients two times.

\section{Two-hybrid screening}

A Gal4-based yeast two-hybrid screen was performed as described previously (Yasugi et al. 1997). The HPV16 E6 bait plasmid was constructed by cloning the full-length HPV16 E6 gene in-frame with the Gal 4 DNA-binding domain (amino acids 1-147) in the pPC97 vector. For the library screen, an activated human $T$ cell CDNA library, kindly provided by Dr. Joshua La Baer $(\mathrm{MGH})$, cloned into the Gal4 activating domain (amino acids 768-881; pPC 86), was transformed into the yeast host strain MaV103 (Mata ura3-53 leu2-3,112 trp1-901 his $\Delta 200$ ade2-101 gal4gal80 4 GAL1::LacZ GAL1::HIS3lys2 SPAL10;URA3) carrying the pPC97-16 E6 plasmid. Transformants were replica plated onto plates lacking histidine and with 3AT (synthetic complete medium [SC]-L-T-H +3AT $30 \mathrm{~mm}$ ). Potential interactors were picked from the 3AT-selective plates. The pPC86-CDNA plasmids were recovered and reintroduced into yeast MaV103 containing pPC97-16 E6. To confirm the interaction, transformants were plated onto SC-L-T-H +3AT 30 $\mathrm{mm}$ plates, Sc-L-T-U plates, and Sc-L-T plates containing X-gal, a substrate for the lacZ-encoded enzyme.

\section{In vitro binding assays}

The HPV E6 in vitro-transcribed and -translated proteins were tested for association with IRF-3 proteins by mixing $7.5 \mu \mathrm{l}$ of ${ }^{35} \mathrm{~S}$-labeled wheat germ extract-translated HPV16, HPV18, HPV11, or HPV6 E6 and $10 \mu \mathrm{l}$ of glutathione-Sepharose beads containing GST-IRF-3 protein. The mixture contained $125 \mu$ of $25 \mathrm{~mm}$ Tris- $\mathrm{HCl}$ (pH 7.4), $50 \mathrm{~mm} \mathrm{NaCl}$ and $25 \mu \mathrm{l}$ of lysis buffer containing $0.1 \mathrm{M} \mathrm{NaCl}, 1 \% \mathrm{NP}-40$, and $0.1 \mathrm{M}$ Tris (pH 7.4). The mixtures were rotated at $4^{\circ} \mathrm{C}$ for $4 \mathrm{hr}$. The beads were collected by centrifugation, washed three times with Iysis buffer, boiled in SDS-gel loading buffer and electrophoresed on SDS-13\% polyacrylamide gels. Gels were fixed, dried, and exposed to Kodak XAR film. Binding of in vitro-translated IRF proteins to GST and GST-E6 proteins was carried out in the same manner.

\section{Immunoprecipitations}

Electroporated COS-7 cells were washed with PBS, scrapped in PBS, and pelleted by centrifugation. Pellets were frozen in dry ice then resuspended in 4 volumes of lysis buffer [ $20 \mathrm{~mm}$ HEPES (pH 7.9), $0.2 \mathrm{~mm}$ EDTA, $0.2 \mathrm{~mm}$ EGTA, 10\% glycerol, and the protease inhibitor cocktail (Pharmingen)]. $\mathrm{KCl}$ (2 $\mathrm{M}$ ) was added to $400 \mathrm{~mm}$ final concentration, and the extracts were rotated at $4^{\circ} \mathrm{C}$ for $30 \mathrm{~min}$ and centrifuged at $12,000 \mathrm{rpm}$ for $10 \mathrm{~min}$. Lysates were precleared with $50 \mu \mathrm{l}$ of a $50 \%$ slurry of protein A-agarose and protein G-agarose (1:1) and $1 \mu$ of normal mouse serum in Iysis buffer. The IP was conducted with $\sim 5 \mathrm{~g}$ of an irrelevant mAb, AU1, or SL-12 mAb. Fifty microliters of a $50 \%$ slurry of protein A-agarose and protein G-agarose (1:1) was added to each lysate, and the suspension was rotated for $2 \mathrm{hr}$ at $4^{\circ} \mathrm{C}$. The protein $A / G$-agarose from each sample was washed three times at $4^{\circ} \mathrm{C}$ with $1 \mathrm{ml}$ of lysis buffer, boiled in SDS-PAGE loading buffer containing DTT and analyzed by PAGE and autoradiography.

\section{Northern analysis}

RNA was harvested from HFK cells with Trizol (GIBCO-BRL). Five micrograms of total RN A was separated on a $1.1 \%$ agaroseformal dehyde gel and transferred to Hybond-N + membrane. The membranes were sequentially hybridized with IFN $\beta, 2^{\prime}-5^{\prime}$ (A), GAPDH, 16 E6 or 6 E6 radiolabeled probes. Gene specific 
signals on each $\mathrm{N}$ orthern blot were quantified by Phosphorlmager analysis (M olecular Dynamics).

Preparation of primary cell culture and infection by retroviral vectors

Primary keratinocytes were isolated from human neonatal foreskins by standard techniques. Briefly, foreskins were cut into several strips and were incubated in dispase $(43.7 \mathrm{mg} / \mathrm{ml})$ overnight. Epidermal layers were removed from the dermis and incubated in trypsin two times at $37^{\circ} \mathrm{C}$ for $15 \mathrm{~min}$. Trypsin containing keratinocytes was removed, pooled, and inactivated by centrifugation through DMEM containing $10 \%$ fetal calf serum. Keratinocytes were maintained in serum-free medium supplemented with human-growth hormone and pituitary extract (GIBCO-BRL).

The amphotropic packaging cell line (PA317) was used to produce recombinant retroviruses LXSN, HPV16 E6, HPV6 E6, HPV16 E7, or HPV17 E6/E7 under the transcriptional control of the Moloney leukemia virus promoter-enhancer sequences (kindly provided by Dr. D. Galloway) (Miller and Rosman 1989; Halbert et al. 1991). The LXSN vectors contain the gene conferring neomycin resistance directed from the SV40 promoter. Recombinant virus was generated according to previously described procedures (Hal bert et al. 1991). Viruses produced from PA 317 cells were used to infect passage 2 human neonatal foreskin keratinocytes. Infected cells were placed under G418 (200 $\mu \mathrm{g} / \mathrm{ml}$ ) selection for $48 \mathrm{hr}$ and then carried for 8 additional days until selection was complete. To determine expression of viral proteins, cells lysates were prepared in RIPA Iysis buffer plus $0.01 \%$ PM SF, and $1 \mu \mathrm{g}$ of aprotinin and leupeptin per milliliter. Lysates were cleared by centrifugation at $15,000 \mathrm{~g}$ at $4^{\circ} \mathrm{C}$ for 5 min. One hundred micrograms of protein was separated by SDSPAGE (12\% polyacrylamide gel), and the levels of HPV16 E7, p53, and IRF-3 were determined by Western analysis as described (Dowhanick et al. 1995). The HPV16 E7 antibody was kindly provided by Dr. K. Münger (Harvard M edical School).

\section{Monoclonal antibody preparation and Western blot analysis}

M onoclonal antibody SL-12 was prepared by injecting mice four times with GST-IRF-3 (amino acids 56-427) protein. Serum samples from immunized mice were checked for antibody titers by assaying the efficiency with which they immunoprecipitated in vitro-translated IRF-3 protein. Spleen cells from the mouse displaying the best response were fused to NS-1 cells (Harlow and Lane 1988). Positive clones were identified by testing the ability of the hybridoma supernatants to immunoprecipitate in vitro-translated IRF-3, and by their efficiency to detect IRF-3 protein by Western analysis.

Cell culture, transfection, CAT, and luciferase assays

C33A, HeLa, L929, SL-12 hybridoma and SiHa cell lines were maintained in DMEM supplemented with $10 \%$ bovine calf serum (GIBCO). Sendai virus (SPAFAS) was used at $200 \mathrm{HAU} / \mathrm{ml}$. MG132 was purchased from Peptides International.

For transient transfections, $60 \mathrm{~mm}$ plates of $50 \%$ confluent cells were transfected by the calcium phosphate procedure (Dowhanick et al. 1995). The DN A-cal cium phospate precipitate was added to the culture and left on cells for 10 to $15 \mathrm{hr}$. The transfection cocktail contained $2 \mu \mathrm{g}$ of reporter plasmid, 1 $\mu \mathrm{g}$ of SV40- $\beta$-gal (pSV $\beta$; Clontech Laboratories, Inc.) and the indicated amounts of expression vectors. The total amount of DNA added to each plate was kept constant by including the appropriate amount of empty expression vector. Precipitate was removed, cells were washed twice with PBS, refed with complete media, and CAT assays were performed as described after 36-48 hr (Sakai et al. 1996). The percent acetylation was quantified by Phosphorlmager (Dynamics) scanning of chromatography plates. Luciferase assays were conducted as described (Bhattacharya et al. 1996). Briefly, six-well plates were seeded with 2.5 E5 cells and the next day were transfected for $15-18 \mathrm{hr}$ by the calcium-phosphate procedure. Luciferase assays were conducted $24 \mathrm{hr}$ after the removal of the DN A/precipitate.

\section{Acknowledgments}

We thank Karl M ünger, Grace Gill, Steve Finkel, M arc Wathelet, and Tom Maniatis for helpful discussions and critical reviews of the manuscript. We also thank James DeCaprio, Charles Ro, and Jianmin Gan for support in production of the monoclonal antibody and Ed Harlow for his constant support. L.V.R. was supported by grant 5 F32 Al09167-02 from the National Institute of Allergy and Infectious Diseases and by a grant from Aid For Cancer Research. A.Y.K. is a Howard Hughes Medical Institute Predoctoral Fellow. This research was supported by a grants from the $\mathrm{N}$ ational Institutes of Health (PO1CA-50661-09 and PO1AI42257-01) to P.M.H.

The publication costs of this article were defrayed in part by payment of page charges. This article must therefore be hereby marked "advertisement" in accordance with 18 USC section 1734 solely to indicate this fact.

\section{References}

Androphy, E.J., N.L. Hubbert, J.T. Schiller, and D.R. Lowy. 1987. Identification of the HPV-16 E6 protein from transformed mouse cells and human cervical carcinoma cell lines. EMBO J. 6: 989-992.

Au, W.C., P.A. Moore, W. Lowther, Y.T. Jaung, and P.M. Pitha. 1995. Identification of a member of the interferon regulatory factor family that binds to the interferon-stimulated response element and activates expression of interferon-induced genes. Proc. Natl. Acad. Sci. 92: 11657-11661.

Band, V., S. Dalal, L. Delmolino, and E.J. Androphy. 1993. Enhanced degradation of p53 protein in HPV-6 and BPV-1 E6 immortalized human mammary epithelial cells. EMBO J. 12: 1847-1852.

Bhattacharya, S., R. Eckner, S. Grossman, E. Oldread, Z. Arany, A. D'Andrea, and D.M. Livingston. 1996. Cooperation of Stat2 and p300/CBP in signalling induced by interferon- $\alpha$. Nature 383: 344-347.

Bosch, F.X., M.M. Manos, N. M unoz, M. Sherman, A.M. Jansen, J. Peto, M.H. Schiffman, V. M oreno, R. Kurman, K.V. Shah, E. Alihonou, S. Bayo, H.C. Mokhtar, S. Chicareon, A. Daudt, E. Delosrios, P. Ghadirian, J.N. Kitinya, M. Koulibaly, C. N gel angel, L.M.P. Tintore, J.L. Riosdalenz, A. SarjadiSchneider, L. Tafur, A.R. Teyssie, P.A. Rolon, M. Torroella, A.V. Tapia, H.R. Wabinga, W. Zatonski, B. Sylla, P. Vizcaino, D. Magnin, J. Kal dor, C. Greer, and C. Wheeler. 1995. Prevalence of human papillomavirus in cervical cancer: A worldwide pespective. J. Natl. Cancer Inst. 87: 796-802.

Bovolenta, C., P. Driggers, M. Marks, J. Medin, A. Politis, S. Vogel, D. Levy, K. Sakaguchi, E. A ppella, J. Coligan, and K. Ozato. 1994. M olecular interactions between interferon consensus sequence-binding protein and members of the interferon regulatory factor family. Proc. Natl. Acad. Sci. 91: 5046-5050.

Brutkiewiewicz, R.R. and R.M. Welsh. 1995. Major histocompatibility complex class I antigens and the control of viral 
infections by natural killer cells. J. Virol. 69: 3967-3971.

Chen, J.J., C.E. Reid, V. Band, and E.J. Androphy. 1995. Interaction of papillomavirus E6 oncoproteins with a putative calcium-binding protein. Science 269: 529-531.

Crook, T., J.A. Tidy, and K.H. Vousden. 1991. Degradation of p53 can betargeted by HPV E6 sequences distinct from those required for $\mathrm{p} 53$ building and transactivation. Cell 67: 547556.

De Maeyer, E. and J. De Maeyer-Guignard. 1988. Interferons and other regulatory cytokines. John Wiley and Sons, $\mathrm{N}$ ew York, NY.

Deng, T. and M. Karin. 1993. JunB differs from C-Jun in its DN A-binding and dimerization domains, and represses c-Jun by formation of inactive heterodimers. Genes \& Dev. 7: 479490.

Desaintes, C., S. Hallez, P. Van Alhen, and A. Burney. 1992. Transcriptional activation of several heterologous promoters by the E6 protein of human papillomavirus type 16. J. Virol. 66: 325-333.

Dey, A., I.A. Atcha, and S. Bagchi. 1997. HPV16 E6 oncoprotein stimulates the transforming growth factor- $\beta 1$ promoter in fibroblasts through a specific GC-rich sequence. Virology 228: 190-199.

Dowhanick, J.J., A.A. McBride, and P.M. Howley. 1995. Suppression of cellular proliferation by the papillomavirus E2 protein. J. Virol. 69: 7791-7799.

Driggers, P.H., B.A. Elenbaas, J.-B. An, I.J. Lee, and K. Ozato. 1992. Two upstream elements activate transcription of major histocompatibility complex class I gene in vitro. Nucleic Acids Res. 20: 2533-2540.

Eisenbeis, C., H. Singh, and U. Storb. 1995. Pip, a novel IRF family member, is a lymphoid-specific, PU.1-dependent transcriptional activator. Genes \& Dev. 9: 1377-1387.

Elston, R.C., S. N apthine, and J. Doorbar. 1998. The identification of a conserved binding motif within human papillomavirus type 16 E6 binding peptides, E6AP, E6BP. J. Gen. Virol. 79: 371-374.

Etscheid, B.G., S.A. Foster, and D.A. Galloway. 1994. The E6 protein of Human Papillomavirus type 16 functions as a transcriptional repressor in a mechanism independent of the tumor suppressor protein, p53. Virology 205: 583-585.

Frazer, I.H. 1996. Immunology of papillomavirus infection. Curr. O pin. Immunol. 8: 484-491.

Fujita, T., Y. Kimura, M. M iyamoto, H. Yamamoto, K. Harada, M. Ishihara, and T. Taniguchi. 1989. Induction of endogenous IFN $-\alpha$ and IFN $-\beta$ genes by a regulatory transcription factor, IRF-1. Nature 337: 270-272.

Hal bert, C.L., G.W. Demers, and D.A. Galloway. 1991. The E7 gene of human papillomavirus type 16 is sufficient for immortalization of human epithelial cells. J. Virol. 65: 473478.

Harada, H., K. Willison, J. Sakakibara, M. Miyamoto, T. Fujita, and T. Taniguchi. 1990. Absence of the type 1 IFN system in EC cells: Transcriptional activator (IRF-1) and repressor (IRF2) genes are developmentally regulated. Cell 63: 303-312.

Harada, H., M. Kitagawa, N. Tanaka, H. Yamamoto, K. Harada, M. Ishihara, and T. Taniguchi. 1993. Anti-oncogenic and oncogenic potentials of interferon regulatory factors -1 and -2 . Science 259: 971-974.

Harlow, E. and D. Lane. 1988. Antibodies: A laboratory manual. Cold Spring Harbor Press, Cold Spring Harbor Laboratory, NY.

Hartwell, L. 1992. Defects in a cell cycle checkpoint may be responsible for the genomic instability of cancer cells. Cell 71: 543-546.

Howley, P.M . 1996. Papillomavirinae: The viruses and their rep- lication. In Fundamental Virology (ed. D.M.K. Bernard, N. Fields, and P.M. Howley), pp. 2045-20076. LippincottRaven, Philadel phia, PA.

Hudson, J.B., M.A. Bedell, D.J. McCance, and L.A. Laimins. 1990. Immortalization and altered differentiation of human keratinocytes in vitro by the E6 and E7 open reading frames of human papillomavirus type 18. J. Virol. 64: 519-526.

Huibregtse, J.M., M. Scheffner, and P.M. Howley. 1991. A cellular protein mediates association of p53 with the E6 oncoprotein of human papillomavirus types 16 or 18. EMBO J. 10: $4129-4135$.

- - - 1993a. Cloning and expression of the CDNA for E6-AP: A protein that mediates the interaction of the human papilIomavirus E6 oncoprotein with p53. Mol. Cell. Biol. 13: 775784.

- - 1993b. Localization of the E6-AP regions that direct HPV E6 binding, association with p53, and ubiquitination of associated proteins. Mol. Cell. Biol. 13: 4918-4927.

Jones, D.L. and K. Münger. 1996. Interactions of the human papillomavirus E7 protein with cell cycle regulators. Semin. Cancer Biol. 7: 327-337.

Kim, T.K. and T. M aniatis. 1997. The mechanism of viral transcriptional synergy of an in vitro assembled interferon- $\beta$ enhanceosome. Mol. Cell 1: 119-129.

Kinoshita, T., H. Shirasawa, Y. Shino, H. M oriya, L. Desbarats, M. Eilers, and B. Simizu. 1997. Transactivation of prothymosin $\alpha$ and c-myc promoters by Human Papillomavirus type 16 E6 protein. Virology 232: 53-61.

Klingel hutz, A.J., S.A. Foster, and J.K. M cDougall. 1996. Telomerase activation by the E6 gene product of human papillomavirus type 16. Nature 380: 79-81.

Lamberti, C., L.C. Morrissey, S.R. Grossman, and E.J. Androphy. 1990. Transcriptional activation by the papillomavirus E6 zinc finger oncoprotein. EMBO J. 9: 1907-1913.

Lechner, M.S., D.H. Mack, A.B. Finicle, T. Crook, K.H. Vousden, and L.A. Laimins. 1992. Human papillomavirus E6 proteins bind p53 in vivo and abrogate p53-mediated repression of transcription. EMBO J. 11: 3045-3052.

Levy, D., D. Kessler, R. Pine, and J. Darnell. 1988. Interferoninduced nuclear factors that bind a shared promoter el ement correlate with positive and negative control. Genes \& Dev. 2: 383-393.

Lowe, S.W., H.E. Ruley, T. Jacks, and D.E. Housman. 1993. p53-dependent apoptosis modulates the cytotoxicity of anticancer agents. Cell 74: 847-849.

Mietz, J.A., T. Unger, J.M. Huibregtse, and P.M. Howley. 1992. The transcriptional transactivation function of wild-type p53 is inhibited by SV40 large T-antigen and by HPV-16 oncoprotein. EMBO J. 11: 5013-5020.

Miller, A.D. and G.J. Rosman. 1989. Improved retroviral vectors for gene transfer and expression. BioTechniques 7: 980-987.

Mittrucker, H.-W., T. Matsuyama, A. Grossman, T.M. Kundig, J. Potter, A. Shahinian, A. Wakeman, B. Patterson, P.S. Ohashi, and T.W. Mak. 1997. Requirment for the transcription factor LSIRF/IRF4 for mature B and T Iymphocyte function. Science 275: 540-543.

Muller, U., U. Steinhoff, L.F.L. Reis, S. Hemmi, J. Pavlovic, R.M. Zinkernagel, and M. Aguet. 1994. Functional role of type I and type II interferons in antiviral defense. Science 264: 1918-1921.

Münger, K., W.C. Phelps, V. Bubb, P.M. Howley, and R. Schlegel. 1989. The E6 and E7 genes of the human papillomavirus type 16 together are necessary and sufficient for transformation of primary human keratinocytes. J. Virol. 63: 4417-4421.

N elson, N., M. Marks, P. Driggers, and K. Ozato. 1993. Inter- 
feron consensus sequence binding protein, a member of the interferon regulatory factor family, suppresses interferon-induced gene transcription. Mol. Cell. Biol. 13: 588-599.

Pan, H. and A.E. Griep. 1994. Altered cell cycle regulation in the lens of HPV-16 E6 and E7 transgenic mice: Implications for tumor suppressor gene function in development. Genes \& Dev. 8: 1285-1299.

Reis, L., H. Harada, J. Wolchok, T. Tanaguchi, and J. Vilcek. 1992. Critical role of a common transcription factor, IRF-1, in the regulation if IFN $-\alpha$ and IFN $-\beta$ inducible genes. EMBO J. 11: 185-193.

Rock, K.L., C. Gramm, L. Rothstein, K. Clark, R. Stein, L. Dick, D. Hwang, and A.L. Goldberg. 1994. Inhibitors of the proteosome block the degradation of most cell proteins and the generation of peptides presented on $\mathrm{MHC}$ class I molecules. Cell 78: 761-771.

Sadowski, I. and M. Ptashne. 1989. A vector for expressing GAL4(1-147) fusions in mammalian cells. Nucleic Acids Res. 17: 7539-7540.

Sakai, H., T. Yasugi, J.D. Benson, J.J. Dowhanick, and P.M. Howley. 1996. Targeted mutagenesis of the human papillomavirus type 16 E2 transactivation domain reveals separable transcriptional activation and DNA replication functions. J. Virol. 70: 1602-1611.

Schafer, S.L., R. Lin, P.A. Moore, J. Hiscott, and P.M. Pitha. 1998. Regulation of type I interferon gene expression by interferon regulatory factor-3. J. Biol. Chem. 273: 2714-2720.

Scheffner, M., K. Munger, J.C. Byrne, and P.M. Howley. 1991. The state of the p53 and retinoblastoma genes in human cervical carcinoma cell lines. Proc. Natl. Acad. Sci. 88: 5523-5527.

Sedman, S.A., M .S. Barbosa, W.C. Vass, N.L. Hubbert, J.A. Hass, D.R. Lowy, and J.T. Schiller. 1991. The full-length E6 protein of human papillomavirus type 16 has transforming and trans-activating activities and cooperates with E7 to immortalize keratinocytes in culture. J. Virol. 65: 4860-4866.

Sherman, L. and R. Schlegel. 1996. Serum-and calcium-induced differentiation of human keratinocytes is inhibited by the E6 oncoprotein of human papillomavirus type 16. J. Virol. 70: 3269-3279.

Shino, Y., H. Shirasawa, T. Kinoshita, and B. Simizu. 1997. Human papillomavirus type 16 E6 protein transcriptionally modulates fibronectin gene expression by induction of protein complexes binding to the cylclic AMP response element. J. Virol. 71: 4310-4318.

Shirasawa, H., M. Jin, K. Shimizu, N. Akutsu, Y. Shino, and B. Simizu. 1994. Transcription-modulatory activity of fulllength E6 and E6*I proteins of Human Papillomavirus type 16. Virology 203: 36-42.

Tamura, T., M. Ishihara, M.S. Lamphier, N. Tanaka, I. Oishi, S. Aizawa, T. Matsuyama, T.W. Mak, S. Taki, and T. Taniguchi. 1995. An IRF-1-dependent pathway of DNA damageinduced apoptosis in mitogen-activated T Iymphocytes. Nature 376: 596-599.

Tanaka, N., M. Ishihara, M. Kitagawa, H. Harada, T. Kimura, T. M atsuyama, M. Lampier, S. Aizawa, T. M ak, and T. Taniguchi. 1994. Cellular commitment to oncogene-induced transformation or apoptosis is dependent on the transcription factor IRF-1. Cell 77: 829-839.

Tanaka, N., M. Ishihara, M.S. Lampier, H. N ozawa, T. Matsuyama, T.W. Mak, S. Aizawa, T. Tokino, M. Oren, and T. Taniguchi. 1996. Cooperation of the tumor suppressors IRF-1 and p53 in response to DN A damage. Nature 382: 816818.

Thanos, D. and T. Maniatis. 1995. Virus induction of human IFN $\beta$ gene expression requires the assembly of an enhanceo- some. Cell 83: 1091-1100.

Tong, X. and P.M. Howley. 1997. The papillomavirus E6 oncoprotein interacts with paxillin and disrupts the actin cytoskel eton. Proc. Natl. Acad. Sci. 94: 4412-4417.

Vaughan, P.S., F. Aziz, A.J. van Wijnen, S. Wu, H. Harada. T. Taniguchi, K.J. Soprano, J.L. Stein, and G.S. Stein. 1995. ACtivation of a cell-cycle-regulated histone gene by the oncogenic transcription factor IRF-2. Nature 377: 362-365.

Vilcek, J. and G.S. Sen. 1996. Interferons and other cytokines. In Fields virology, 3rd. ed. (ed. B.N. Fields, P. M. Howley, and D.M. Knipe), pp. 375-400. Raven Press, N ew York, NY.

Wathelet, M., P.M. Berr, and G.A. Huez. 1992. Regulation of gene expression by cytokines and virus in human cells lacking the type-1 interferon locus. Eur. J. Biochem. 206: 901910.

Wathelet, M., C.H. Lin, B. Parekh, L.V. Ronco, P.M. Howley, and T. Maniatis. (1998). Virus infection induces the assembly of coordinately activated transcription factors on the IFN $-\beta$ enhancer in vivo. Mol. Cell 1: 507-518.

Weaver, B.K., K. Prasanna Kumar, and N.C. Reich. 1998. Interferon regulatory factor 3 and CREB-binding protein/p300 are subunits of double-stranded RNA-activated transcription factor DRAF1. Mol. Cell. Biol. 18: 1359-1386.

Werness, B.A., A.J. Levine, and P.M. Howley. 1990. Association of human papillomavirus types 16 and 18 E6 proteins with p53. Science 248: 76-79.

Yasugi, T., J.D. Benson, H. Sakai, M. Vidal, and P.M. Howley. 1997. Mapping and characterization of the interaction domains of human papillomavirus type $16 \mathrm{E} 1$ and E2 proteins. J. Virol. 71: 891-899.

Zhang, L. and J.S. Pagano. 1997. IRF-7, a new interferon regulatory factor associated with epstein-barr virus latency. Mol. Cell. Biol. 17: 5748-5757.

zur Hausen, H. 1996. Papillomavirus infections-a major cause of human cancers. Biochim. Biophys. Acta 1288: F55-F78. 


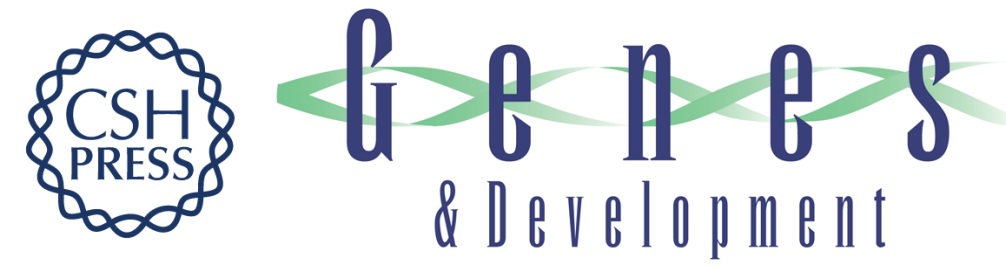

\section{Human papillomavirus 16 E6 oncoprotein binds to interferon regulatory factor- 3 and inhibits its transcriptional activity}

Lucienne V. Ronco, Alla Y. Karpova, Marc Vidal, et al.

Genes Dev. 1998, 12:

Access the most recent version at doi:10.1101/gad.12.13.2061

References This article cites 64 articles, 30 of which can be accessed free at: http://genesdev.cshlp.org/content/12/13/2061.full.html\#ref-list-1

License

Email Alerting

Receive free email alerts when new articles cite this article - sign up in the box at the top Service right corner of the article or click here.

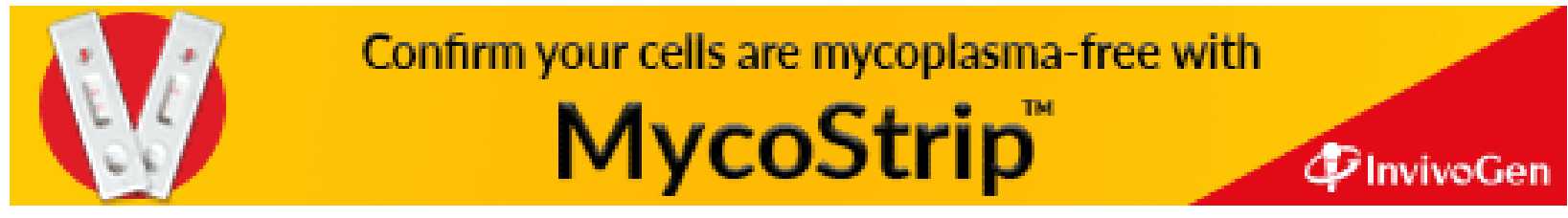

